\title{
ESTABLISHMENT OF PRIMARY KERATINOCYTE CULTURE FROM HORSE TISSUE BIOPSATES
}

\author{
Jernej OGOREVC ${ }^{1,2}$, Tjaša LAPANJA ${ }^{2,3}$, Klavdija POKLUKAR ${ }^{2,4}$, Natalija TOMINŠEK ${ }^{2,5}$, \\ Peter DOVČ 6
}

Received October 23, 2015; accepted November 20, 2015. Delo je prispelo 23. oktobra 2015, sprejeto 20. novembra 2015.

\begin{abstract}
Establishment of primary keratinocyte culture from horse tissue biopsates

Primary cell lines established from skin tissue can be used in immunological, proteomic and genomic studies as in vitro skin models. The goal of our study was to establish a primary keratinocyte cell culture from tissue biopsates of two horses. The primary keratinocyte cell culture was obtained by mechanical and enzymatic dissociation and with explant culture method. The result was a heterogeneous primary culture comprised of keratinocytes and fibroblasts. To distinguish epithelial and mesenchymal cells immunofluorescent characterisation was performed, using antibodies against cytokeratin 14 and vimentin. We successfully at attained a primary cell line of keratinocytes, which could potentially be used to study equine skin diseases, as an animal model for human diseases, and for cosmetic and therapeutic product testing.
\end{abstract}

Key words: molecular biology / primary cell culture / skin / horses / keratinocytes

\section{INTRODUCTION}

Because of the economic value and the number of animals (in 2013 there were almost 60 million registered horses) (Faostat, 2015), horses (Equus caballus) represent a group of economically important animals. A significant share of veterinary research has focused on researching and treating diseases in horses. In some cases, a horse also became an animal model for human diseases, for example in melanoma studies (Seltenhammer et al., 2004) and muscle, joints, tendons, ligaments, and bone injuries
Vzpostavitev primarne celične kulture konjskih keratinocitov iz biopsij

Primarna celična linija iz kožnega tkiva lahko služi za imunološke, proteomske in genomske raziskave kot in vitro model kože. Cilj naše študije je bila vzpostavitev primarne celične linije keratinocitov iz biopsije kožnega tkiva dveh konjev. Primarno celično kulturo smo pridobili z mehansko in encimsko razgradnjo tkiva in $\mathrm{z}$ metodo izraščanja celic. Rezultat je bila heterogena kultura keratinocitov in fibroblastov. Za imunološko karakterizacijo smo uporabili protitelesa proti citokeratinu 14 in vimentinu ter poskusili obogatiti delež keratinocitov v kulturi. Uspešno smo pridobili primarno celično linijo keratinocitov, ki je potencialno uporabna za preučevanje kožnih bolezni konjev, kot živalski model za preučevanje človeških bolezni in za testiranje kozmetičnih izdelkov ter zdravil.

Ključne besede: molekularna biologija / primarna celična kultura / koža / konji / keratinocite

(Nagy et al., 2014). In research that is focusing on analysing various diseases, their mechanisms of action, and subsequent physiological changes and potential treatments, the use of in vitro models is crucial. It enables the application of immunological, genomic and proteomic studies on a tissue culture of an organ, excluding the systemic and environmental effects and providing more comparable results as in in vivo studies. Additionally, in vitro experiments are more reasonably priced and less ethically controversial.

The skin represents the largest organ in mam-

\footnotetext{
1 Univ. of Ljubljana, Biotechnical Fac., Dept. of Animal Science, Groblje 3, SI-1230 Domžale, Slovenia, e-mail: jernej.ogorevc@bf.uni-lj.si

2 The authors contributed equally to the work

3 Same address as 1, Study program in biotechnology, e-mail: tjasalapanja@gmail.com

4 Same address as 3, e-mail: klavdija.poklukar@gmail.com

5 Same address as 3, e-mail: natalija.tominsek@gmail.com

6 Same address as 1, peter.dovc@bf.uni-lj.si
} 
malian body that is divided in three major layers: dermis, epidermis and subcutis. The major cell type in the outer layer of skin are keratinocytes, which represent a protective layer. The most prevalent cell type in dermis are fibroblasts, which produce different growth factors, needed for proliferation of keratinocytes. The types of cells found in subcutis are macrophages, fibroblasts and adipose cells (Orazizadeh et. al., 2015). Research on horse skin cell lines resulted in a range of applications, including establishment of primary keratinocyte cultures for researching extracellular matrix proteins, associated with skin disseases (Visser and Pollit, 2010) and development of an equine skin-equivalent model that could be used in regenerative medicine, pathogenesis research, and biological and pharmacological studies (Cerrato et al., 2014). However, very few protocols for preparation and sustainment of horse primary cell lines have been developed (e.g. Wunn et al., 1999; Aasen and Bellmonte, 2010).

The purpose of this study was to establish a primary horse skin epithelial cell culture and to characterise cell types present in the derived culture. The study is interesting for researchers studying degenerative skin and hair diseases in horses and possibly in other species. For example, in human medicine optimisation of protocols for sustaining keratinocyte cell lines became important as a part of production process of skin substitute that is used for treatment after burns and other larger tissue damages. Various diseases in horse, such as hereditary equine regional dermal asthenia (HERDA), alopecia areata (AA) and incontinentia pigmenti (IP), known in different breeds, are associated with skin lesions, hair or mane loss and other related health problems. Detecting skin and hair diseases is usually a big economic burden for breeders. At the same time, these diseases are mostly incurable, largely due to the lack of information about the illness. Skin models employing primary cells could be used for pathogenesis research and understanding of such diseases and could be useful as a starting point in drug screening/testing studies (Guo and Jahoda, 2009).

\section{MATERIALS AND METHODS}

\subsection{ESTABLISHMENT AND PROPAGATION OF THE CELL CULTURE}

Skin biopsates containing epidermis and dermis were aseptically removed from neck area below the mane of two Appaloosa breed horses (Equus caballus). From each horse two samples of approximately $2 \mathrm{~cm}^{2}$ were taken and transferred into phosphate buffered saline (PBS) with added antibiotics $(100 \mathrm{mg} / \mathrm{mL}$ streptomycin and
$100 \mathrm{mg} / \mathrm{mL}$ penicillin). Tissue was stored at $4{ }^{\circ} \mathrm{C}$ during transport and processed immediately. Enzymatic and tissue explant methods were used for establishment of primary cell culture.

For enzymatic digestion, the tissue biopsates were incubated in dispase II $(2.4 \mathrm{U} / \mathrm{mL})$ at $4{ }^{\circ} \mathrm{C}$ for 18 hours. After incubation of tissue epidermis was separated from dermis. The epidermis was cut into small pieces and incubated in $0.25 \%$ trypsin with $0.05 \%$ EDTA for 30 minutes at $37^{\circ} \mathrm{C}$ (Vissar and Pollitt, 2010). During the incubation, the samples were shook every several minutes. Trypsin was inactivated with addition of medium containing serum. The liquid phase was separated from the remaining tissue pieces and centrifuged at $1000 \mathrm{rpm}$ for 10 minutes to collect the dissociated cells in suspension for seeding. Fresh trypsin can be added to the processed tissue and the process repeated for several times, until the tissue is fully dissociated. The collected cells were seeded in untreated plastic culture flasks and Geltrex (Gibco)-covered culture flasks. Thin-layer Geltrex method (described in the manufacturer's protocol) was used to cover plastic surface with a mixture of DMEM and Geltrex in 1:100 ratio. DMEM/F12 (D6421, Sigma) supplemented with $10 \% \mathrm{FBS}, 10 \mathrm{ng} / \mathrm{mL}$ EGF, $5 \mu \mathrm{g} / \mathrm{mL}$ insulin, $0.4 \mu \mathrm{g} / \mathrm{mL}$ hydrocortisone, $0.1 \mu \mathrm{g} / 10 \mathrm{~mL}$ cholera toxin, $2 \mathrm{mmol} / \mathrm{L}$ glutamine, and $5 \mu \mathrm{g}$ transferrin was used to grow the cells (growth medium). The cells were grown at $37^{\circ} \mathrm{C}$ and $5 \% \mathrm{CO}_{2}$.

Differential trypsinisation was used to obtain enriched keratinocyte culture. The primary culture, containing keratinocytes and fibroblasts, was incubated in a solution of $0.125 \%$ trypsin-EDTA for several minutes, with continuous microscopic observation. When most of the fibroblasts detached the reaction was stopped. The solution containing fibroblasts was removed, while keratinocytes remain attached. Because of the difference in the adhesion potential of the two predominant cell types, we were able to obtain two separate, almost pure keratinocyte and fibroblast cell lines.

Solution of $0.25 \%$ trypsin-EDTA was used to detach the cells for subculturing. The cells were split in a 1:5 ratio and cultivated further in the growth medium. A mixture of basic medium, $20 \%$ FBS and $10 \%$ DMSO was used for freezing the cells. The cells were frozen in a freezing container that provides a cooling rate of $1{ }^{\circ} \mathrm{C}$ per minute, kept at $-80^{\circ} \mathrm{C}$ overnight, and transferred in liquid nitrogen for long term storage.

Alternatively, for explant culture method tissue was mechanically minced and small parts of the tissue seeded directly in culture dishes, containing the growth medium. All other procedures were the same as described previously. 


\subsection{IMMUNOFLUORESCENT STAINING}

The cells, grown for seven days, were washed in PBS and fixed in $4 \%$ formalin for 5 minutes. Cells were permeabilised with $1 \%$ Triton-X in PBS and incubated for 20 minutes. The fixed cells were washed with PBS and blocked with $10 \%$ goat serum for 30 minutes at room temperature. Monoclonal mouse (Santa Cruz Biotech sc-53253) and polyclonal rabbit (Covance PRB-155P) antibodies against cytokeratin 14 and monoclonal mouse antibody against vimentin (Santa Cruz Biotech sc-73262) were used to distinguish between keratinocytes and mesenchymal (fibroblast) cells. The cells were incubated overnight at $4{ }^{\circ} \mathrm{C}$ in a solution of primary antibodies (1:100). After three 5-minute washes in PBS, they were incubated for 60 minutes in a dilution (1:200) of labelled secondary goat-anti-rabbit antibody (Invitrogen, Alexafluor 488, A11008) to visualize attachment of polyclonal cytokeratin 14 and in goat-anti-mouse (Alexafluor 594, A11037) antibody to visualize attachment of primary mouse monoclonal antibodies (cytokeratin 14 and vimentin). After incubation in secondary antibodies, the cells were washed again for several times in PBS and counterstained with DAPI (1:1000) for 3 minutes to visualize nuclear DNA. After washing in PBS, the cells were observed under fluorescent microscope (Nikon Eclipse TE, 2000).

\section{RESULTS AND DISCUSSION}

Tissue explant and enzymatic method were used for establishment of the primary keratinocyte cell culture. The enzymatic dissociation of the tissue resulted in a heterogeneous mixture of cells, predominantly consisting of keratinocytes and fibroblasts. Adherent cells that explanted from attached pieces of the tissue consisted mainly of keratinocytes, however the yield of cells was much lower, compared to enzymatic method. In tissue explant method, cell outgrowths growing from mechanically processed tissue were observed after several days; e.g. five days as showed in Figure 1. In enzymatic method, the dissociated cells attached, but the proliferation rate was low in the first few days. After several days in culture the cells started to proliferate and formed islands of densely packed keratinocytes and more sparsely growing fibroblasts (Fig. 2a). The cells attached to both - Geltrexmatrix and plastic surface, however, proliferation was faster on Geltrex. Witte and Kao (2005) showed that extracellular matrix is extremely important in cell adhesion and proliferation. It can also affect the development of epithelial cells, their morphogenetic activity and even survival. Evidence suggests that the absence of appropri- ate matrix might be the reason for progressive necrosis of epithelial cells on plastic surface (Freeman et al., 1978).

After 7 days of cultivation, keratinocytes formed large clusters (Fig. 2b). Orazizadeh et al., 2015 compared enzymatic and explant methods for human foreskin derived keratinocytes in the absence of feeder layer. They noticed that after enzymatic treatment no attached cells were found after 7 to 10 days. With explant method they found separated keratinocytes after 24 hours that latter formed large clusters of cells. Our findings differ from that, namely, the yield of cells was higher when enzymatic method was used. After 10 days in culture we observed large colonies of keratinocytes, surrounded by fibroblasts. Witte and Kao (2005) reported that growth and adhesion of keratinocytes can be increased in the presence of mesenchymal cells (fibroblasts). Interleukin 1 beta (IL-1 $\beta$ ) is released by keratinocytes and stimulates production of diverse fibroblast growth factors (FGF) in mesenchymal cells, including keratinocyte growth factor (KGF) that enhances migration and proliferation of keratinocytes (Witte and Kao, 2005).

Fibroblasts are normally unwanted in primary cell cultures. Fibroblast contamination in the culture was decreased with mechanical removal of dermis in the skin biopsate (using scalpel) and with incubation in dispase II that enabled physical separation of epidermal and dermal tissue. For additional separation of keratinocytes from fibroblasts the differential trypsinisation was used. In case of tissue explant method, we obtained a relatively pure keratinocyte culture. Guo and Jahonda (2009) reported that fibroblasts migrate out of adult skin explant later than keratinocytes. With well-timed removal of tissue pieces from the culture, we were able to avoid fibroblast contamination.

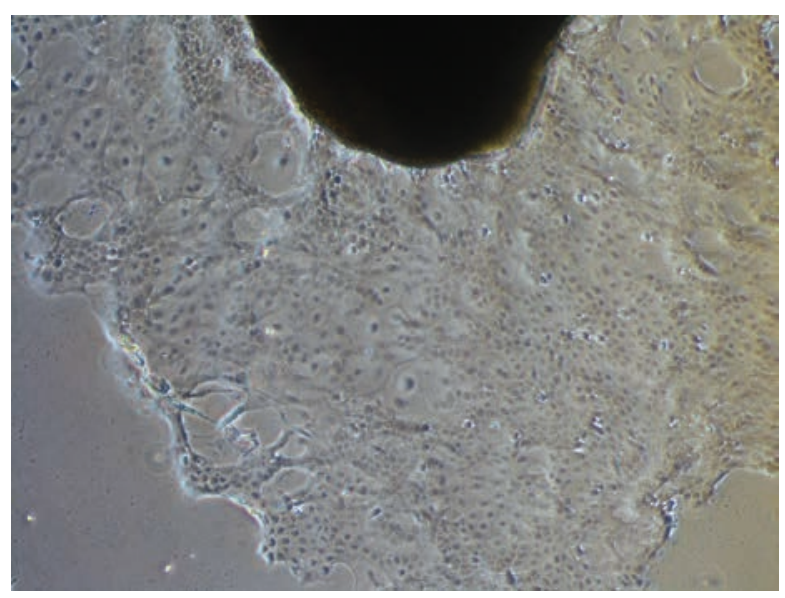

Figure 1: Explant culture of keratinocytes with visible piece of the attached skin tissue (magnification $x 40$ )

Slika 1: Kultura keratinocitov, pridobljena $z$ metodo izraščanja celic, $z$ vidnim delom kožnega tkiva (40 x povečava) 


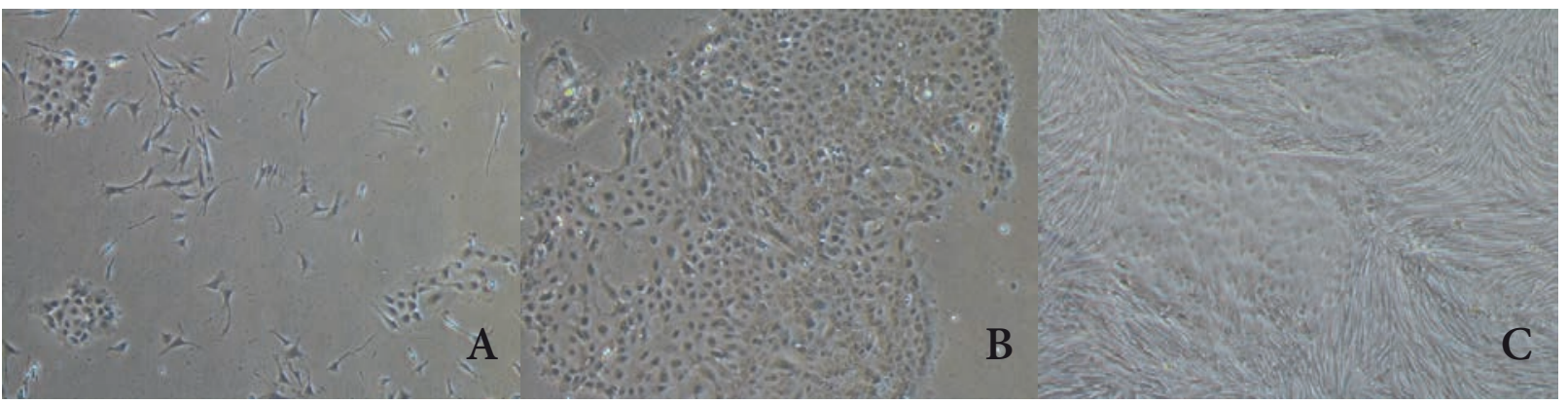

Figure 2: Keratinocytes and fibroblasts in the culture established with enzymatic method during day 2 (A, magnification $x 40)$, day 7 (B, magnification $x$ 40), and day 10 (C, magnification $x$ 40)

Slika 2: Kultura keratinocitov in fibroblastov, pridobljena $z$ encimsko metodo drugi dan ( $A, 40 x$ povečava), 7 dan (B, $40 \times$ povečava) in 10 dan (40 x povečava)

Cells were characterised based on morphological characteristics and by immunofluorescent staining. Antibodies against cytokeratin 14, distinct for keratinocytes, and antibody against vimentin, distinct for fibroblasts, were used for basic characterisation. Cytokeratins are cytoskeletal proteins distinctive for epithelial cells. Cytokeratin 14 forms hemidesmosomes together with cytokeratin 5 , the structures on the inner basal surface of keratinocytes that attach cells to the extracellular matrix, and consequently maintain integrity of the basal layer (Nobusawa et. al., 2014). Positive staining against vimentin is often used for identification of fibroblasts. It is a type III cytoskeletal intermediate filament (IF) that is expressed in mesenchymal cells. Furthermore, vimentin is used in identifying cells that undergo an epithelial-tomesenchymal transition (EMT). During EMT epithelial cells drastically change their shape and motile behaviour on the point of differentiating into mesenchymal cells (Mendez et al., 2010).

Immunofluorescent co-staining showed presence of both markers in the culture - epithelial (keratinocytes) and mesenchymal (fibroblast) cells (Fig. 3). Epithelial cell morphology and expression of cytokeratin 14 proves that cells in the primary culture belong to keratinocyte lineages. Vimentin was expressed only in fibroblasts, which can also be recognised by their elongated spindle shaped morphology (Vissar and Pollit, 2010).

We found that keratinocytes from equine skin were able to proliferate in the primary culture for at least four passages, without any visible change in the morphology and proliferation rate, estimated by the time needed to overgrow the growth surface between the passages. Cells adhere well to Geltrex, which we used instead of collagen type I (Vissar and Pollit, 2010), but can attach and proliferate also on plastic surface. The established cell culture can be frozen and recovers with approximately $80 \%$ viability rate. The cells are available for further research, for example, as a research model of horse skin diseases, product testing and toxicity screens in pharmaceutical and cosmetic industry, or as an animal model for studying certain human skin diseases.

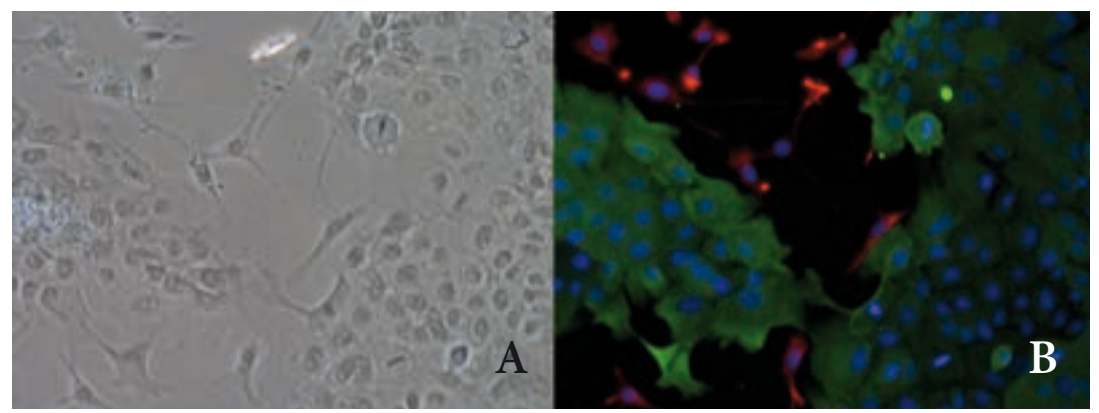

Figure 2: Mixed culture of keratinocytes and fibroblasts after immunostaining under bright field (A) and fluorescent (B) illumination (magnification $\times 200$ ). Keratinocytes stained with antibodies against cytokeratin 14 (green) and fibroblasts stained with antibodies against vimentin (red). Nuclei were counterstained with DAPI (4', 6-diamidine-2'-phenylindole dihydrochloride).

Slika 2: Mešana kultura keratinocitov in fibroblastov pod svetlobnim (A) in fluorescentnim mikroskopom (B) (magnification x 200). Keratinociti so obarvani s protitelesom proti citokeratinu 14 (zelena), fibroblasti pa s protitelesom proti vimentinu (rdeča). Jedra so obarvana z DAPI (4', 6-diamidin-2'fenilindol dihidroklorid). 


\section{REFERENCES}

Aasen T., Izpisúa Belmonte J.C. Isolation and cultivation of human keratinocytes from skin or plucked hair for the generation of induced pluripotent stem cells. 2010. Nature Protocols, 5: 371-382. doi:10.1038/nprot.2009.241

Cerrato S., Ramio-Lluch L., Brazis P., Rabanal R.M., Fondevila D., Puigdemont A. 2014. Establishment and characterisation an of equine skin-equivalent model. Veterinary Dermatology, 25: 475-e77. doi:10.1111/vde.12134

FAOSTAT. 2013. Production/Live Animals. http://faostat3.fao. org/browse/Q/QA/E (16. Oct. 2015)

Freeman A.E., Igel H.J., Herrman B.J., Kleinfeld K.L. 1976. Growth and characterization of human skin ephitelial cell cultures. In vitro, 12: 352-362. doi:10.1007/BF02796313

Guo A., Jahoda C.A.B. 2009. An improved method for homan keratinocyte culture from skin explants: Cell expansion is linked to markers of activated progenitor cells. Experimental Dermatology, 18: 720-726. doi:10.1111/j.16000625.2009.00900.x

Mendez M.G., Kojima, S.I., Goldman, R.D. 2010. Vimentin induces changes in cell shape, motility, and adhesion during the epithelial to mesenchymal transition. The FASEB Journal, 24, 6: 1838-1851. doi:10.1096/fj.09-151639

Nagy K., Sung H.K., Zhang P., Laflamme S., Vincent P., AghaMohammadi S., Woltjen K., Monetti C., Michael I.P., Smith L.C., Nagy A. 2011. Induced pluripotent stem cell lines de- rived from equine fibroblasts. Stem Cell Reviews, 7: 693702. doi:10.1007/s12015-011-9239-5

Nobusawa A., Sano T., Negishi A., Yokoo S., Tetsunari O. 2014. Immunohistochemical staining patterns of cytokeratins 13, and 17 in oral epithelial dysplasia including orthokeratotic dysplasia. Pathology International, 64: 20-27. doi:10.1111/ pin. 12125

Orazizadeh M., Hashemitabar M., Bahramzadeh S., Dehbashi F.N., Saremy S. 2015. Comparison of the enzymatic and explant methods for the culture of keratinocytes isolated from human foreskin. Biomedical Reports, 3, 3: 304-308

Seltenhammer M.H., Heere-Ress E., Brandt S., Druml T., Jansen B., Pehamberger H., Niebauer G.W. 2004. Comparative histopathology of grey-horse-melanoma and human malignant melanoma. Pigment Cell Research, 17: 674-81. doi:10.1111/j.1600-0749.2004.00192.x

Visser M.B., Pollitt C.C. 2010. Characterization of extracellular matrix macromolecules in primary cultures of equine keratinocytes. BMC Veterinary Research, 6, 16: 1-8. doi:10.1186/1746-6148-6-16

Witte R.P., Kao W.J. 2004. Keratinocyte-fibroblast paracrine interaction: the effects of substrate and culture condition. Biomaterials, 26: 3673-3682. doi:10.1016/j.biomaterials.2004.09.054

Wunn D., Wardrop K.J., Meyers K., Kramer J., Ragle C. 1999. Culture and characterisation of equine terminal arch endotelial cells and hoof keratinocytes. American Journal of Veterinary Research, 60, 1: 128-132 